\title{
Pengaruh Kompensasi, Lingkungan Kerja dan Kepuasan Kerja terhadap Keinginan Berpindah Karyawan PT Panin Bank Tbk di Jakarta
}

\begin{abstract}
Ardy Firman Syah'1)
1)Badan Kepegawaian Negara, Jakarta, Indonesia Corresponding author : ardyfirmansyah24@gmail.com

Abstract:

In this research, the aim is to perform systematic testing of the Effect of Compensation, Work Environment and Job Satisfaction on Turnover Intention Employees of PT Panin Bank Tbk in Jakarta. Samples used are employees of PT. Panin Bank Tbk in Jakarta with the number of respondents as many as 80 people. The analysis used is multiple linear regression. This study tested 4 variables: Compensation (X1), Work Environment (X2), and Job Satisfaction (X3) as independent variable and Turnover Intention $(\mathrm{Y})$ as dependent variable. Partial test shows that compensation effect with regression coefficient of $-0,300$ (negative and significant) to Turnover Intention. The working environment also significantly negatively influences the regression coefficient of -0.214 to Turnover Intention. Furthermore, job satisfaction also has a significant negative effect with regression coefficient of -0.188 against Turnover Intention.
\end{abstract}

Keywords: Compensation, Work Environment, Job Satisfaction, and Turnover Intention

\section{Abstrak:}

Tujuan penelitian ini adalah untuk melakukan pengujian secara sistematis Pengaruh Kompensasi, Lingkungan Kerja dan Kepuasan Kerja terhadap Keinginan Berpindah karyawan PT Panin Bank Tbk di Jakarta. Sampel yang digunakan adalah karyawan PT. Panin Bank Tbk yang ada di Jakarta dengan jumlah responden sebanyak 80 orang. Analisis yang digunakan adalah regresi linear berganda. Penelitian ini menguji 4 variabel yaitu Kompensasi (X1), Lingkungan Kerja (X2), dan Kepuasan Kerja (X3) sebagai variabel bebas dan Keinginan Berpindah (Y) sebagai variabel terikat. Pengujian secara parsial menunjukkan bahwa kompensasi berpengaruh dengan koefisien regresi sebesar -0,300 (negatif dan signifikan) terhadap keinginan berpindah. Lingkungan kerja juga berpengaruh negatif secara signifikan dengan koefisien regresi sebesar -0.214 terhadap keinginan berpindah. Selanjutnya, kepuasan kerja juga mempunyai pengaruh negatif secara signifikan dengan koefisien regresi sebesar - 0.188 terhadap keinginan berpindah.

Kata Kunci: Kompensasi, Lingkungan Kerja, Kepuasan Kerja, dan Keinginan Berpindah 


\section{PENDAHULUAN}

\section{Latar Belakang}

Persaingan di dunia perbankan Indonesia saat ini tampak semakin ketat. Masingmasing bank terus berinovasi dan berkompetensi dalam berupaya menarik minat dan perhatian masyarakat sebagai mitra yang paling lengkap untuk melakukan berbagai transaksi keuangan sehari-hari. Bank Panin sebagai perusahaan keuangan berorientasi profit tentunya memiliki salah satu konsep bahwa sumber daya manusia (SDM) atau karyawan adalah salah satu aset penting yang mampu menggerakkan sumber-sumber daya lainnya. Perusahaan atau organisasi perlu mengelola karyawan demi mencapai sasarannya secara efisien dan efektif sebagai salah satu aset penting atas investasi yang berkaitan dengan manusia. Karyawan yang memiliki potensi harus dipertahankan agar tidak berdampak pada keinginan untuk berpindah pada perusahaan lain (turn-over intention). Keinginan berpindah karyawan dapat berupa keinginan yang telah muncul dalam benaknya, pemutusan hubungan kerja (PHK), mengundurkan diri, maupun perpindahan ke luar unit organisasi.

Pada 2017, strategi pengembangan Sumber Daya Manusia (SDM) di Bank Panin mengikuti proses analisis dan identifikasi terhadap kebutuhan, ketersediaan, dan kesiapan kompetensi SDM dalam organisasi yang disesuaikan dengan arah strategi bisnis. Pengembangan SDM ini juga memperhatikan tuntutan persaingan yang ketat di pasar tenaga kerja perbankan profesional. Salah satu fokus strategi bidang SDM adalah optimalisasi dan peningkatan produktivitas karyawan yang sudah ada, serta penguatan organisasi di kantor cabang untuk mendukung pemenuhan karyawan yang efektif dan berkualitas. Namun pada kenyataannya, komposisi karyawan pada Bank Panin tidak sesuai dengan perencanaan strategi bisnis yang menyebabkan terjadinya penghambatan pada semua lini bisnis pada bank tersebut.

Kondisi SDM pada setiap unit di Bank Panin perlu penambahan dengan memperhatikan latar belakang pengalaman dan gelar akademik pada setiap karyawan. Faktanya, angka keinginan berpindah karyawan masih terlihat relatif tinggi sehingga menyebabkan proses bisnis dan perkembangan setiap lini unit terhambat yang berdampak pada kurangnya yang sesuai dengan unit kerja yang akan diisi kembali untuk dapat berkontribusi secara optimal dengan memajukan proses bisnis yang ada dan tenaga kerja yang tersedia.

Tabel 1

Data Berpindah Karyawan PT. Bank Panin Tbk

\begin{tabular}{ccc}
\hline No. & Tahun & $\begin{array}{c}\text { Prosentase } \\
\mathbf{( \% )}\end{array}$ \\
\hline 1 & 2015 & 3,54 \\
2 & 2016 & 15,90 \\
3 & 2017 & 11,47 \\
\hline \multirow{2}{*}{ Sumber : Laporan Tahunan Bank Panin Tahun $2015-2017$ (data diolah) }
\end{tabular}

Data berpindah pada karyawan Bank Panin selama tiga tahun terakhir, dapat pula dilihat lebih spesifik berdasarkan 3 Divisi internal pada tabel berikut:

Tabel 2

Data Berpindah Karyawan PT. Bank Panin Tbk berdasarkan Divisi

\begin{tabular}{|c|c|c|c|c|}
\hline Tahun & Divisi & $\begin{array}{l}\text { Jml Resign } \\
\text { /Bertambah }\end{array}$ & $\begin{array}{c}\text { Jml Resign / } \\
\text { Bertambah } \\
\text { Per Tahun }\end{array}$ & $\begin{array}{c}\text { Jumlah } \\
\text { Karyawan per } \\
\text { 31 Desember }\end{array}$ \\
\hline
\end{tabular}




\begin{tabular}{llrll}
\hline \multirow{2}{*}{2015} & Pemasaran & -312 & -584 & 15.908 \\
& Operasional & -205 & & \\
& SDM & -67 & & 13.379 \\
2016 & Pemasaran & -2.012 & -2.529 & \\
& Operasional & -463 & & 11.844 \\
& SDM & -54 & -1.535 & \\
2017 & Pemasaran & -132 & & \\
& Operasional & -1.403 & &
\end{tabular}

Data emprik yang diperoleh peneliti berdasar tabel 1.1, dapat diketahui bahwa karyawan Bank Panin mempunyai rasa ketidakpuasan dalam hal lingkungan kerja maupun kompensasi. Apabila seseorang puas akan pekerjaan yang dijalaninya, maka rasa senang pun akan datang, terlepas dari rasa tertekan, sehingga akan menimbulkan rasa aman dan nyaman untuk selalu bekerja di lingkungan kerjanya.

Berdasarkan tabel 1.1, tingkat keinginan berpindah pada karyawan Bank Panin menunjukkan adanya fluktuasi dari tahun ke tahun. Pada tahun 2017, pada tabel 1.1 prosentase pertumbuhan karyawan mengalami penurunan dibandingkan dengan tahun 2016 dan tahun 2015. Dampak tersebut dikarenakan karyawan yang keluar tidak hanya dari staf biasa, akan tetapi dari level manajer maupun pemimpin tim (team leader). Dari data tabel 1.2 diatas dapat dilihat bahwa perusahaan Panin Bank terdapat turnover dalam jumlah pegawainya dari tahun 2015, 2016 dan 2017 di 3 sektor yaitu Divisi Pemasaran, Divisi Operasional dan Divisi SDM yang antara lain dapat disebabkan oleh banyak faktor dan didapat berdasarkan hasil wawancara pada tiap karyawan Panin Bank.

Pertama, kompensasi. Berdasarkan hasil wawancara dengan karyawan Panin Bank pada Kantor Cabang Jakarta Plaza Pasifik, mayoritas karyawan mengeluhkan kompensasi yang kurang baik dan karyawan lainnya berpendapat baik. Hal ini sangat memprihatinkan karena terhitung dari 53 persen karyawan yang sudah dipromosikan untuk jabatan yang lebih tinggi (supervisor), kompensasi gajinya hanya berbeda sedikit dengan karyawan biasa. Bahkan manajer cabang tertentu bergaji sama dengan kepala kasir (head teller).

Kedua, lingkungan kerja. Aspek lingkungan kerja yang belum memenuhi harapan dari karyawan Bank Panin adalah dari ketersediaan alat penunjang pekerjaan seperti server yang sering drop ketika kegiatan operasional berlangsung dan berdampak pula pada mesin ATM yang sering offline. Lalu mesin fotokopi yang sering mengalami masalah dan dapat menghambat kegiatan operasional ketika terdapat transaksi yang digunakan untuk fotokopi KTP, buku tabungan dan lain-lain. Ketersediaan ATK yang telat pengirimannya, dan berdampak pada terbatasnya formulir aplikasi transfer, slip setoran, maupun pembukaan rekening tabungan. Selain itu, dari aspek komponen genetik lingkungan kerja, antar karyawan Bank Panin masih tergolong kurang kondusif dalam mendukung unitnya masingmasing.

Ketiga, kepuasan kerja. Karyawan Bank Panin mempunyai rasa ketidakpuasan dalam hal lingkungan kerja maupun kompensasi yang didapat. Dalam hal ini, karyawan merasa tidak puas atas hasil yang didapat dikarenakan berbanding terbalik dengan ekpektasi dari tiap karyawan.

Keempat, disiplin kerja. Pada faktor ini tingkat disiplin kerja karyawan Panin Bank menjadi menurun ketika merasa adanya ketidakpuasan atas hasil yang didapat pada karyawan. Tingkat absensi yang semakin memburuk dan waktu luang yang belum efisien dilakukan oleh karyawan untuk mengevaluasi kinerja dari tiap cabang dan wilayah 
dikarenakan tiap karyawan ingin tidak terlalu lama di tempat kerja dan merasa tidak mempunyai tanggung jawab lebih untuk loyal kepada perusahaan.

Kelima, adapun unsur komitmen pada karyawan Panin Bank masih dijadikan suatu masalah, dimana pada setiap karyawan kurang adanya sikap loyalitas dan mengikuti perkembangan bisnis dari sasaran target yang sudah ditetapkan oleh pihak manajemen dan dijadikan key performance indikator dari tiap karyawan. Dari tiap karyawan hanya menjalankan proses bisnis seperti biasa dan tidak adanya manuver dalam mempromosikan dan menjual produk baru ataupun mengikuti lini bisnis baru yang sudah ditetapkan oleh pihak manajamen.

Keenam, keinginan berpindah (turn-over) para karyawannya masih tergolong cukup tinggi dari tahun ke tahun. Dalam mengatasi tingkat keinginan berpindah yang tinggi dengan banyaknya karyawan yang keluar seharusnya perusahaan cepat mengambil tindakan untuk job opening secara masal, namun Bank Panin dalam perekrutan karyawannya tergolong minim dibandingkan dengan bank lainnya.

Berdasarkan latar belakang di atas, maka judul yang dipilih peneliti adalah: "Pengaruh Kompensasi, lingkungan kerja, dan kepuasan kerja terhadap Keinginan Berpindah pada Karyawan PT. Bank Panin, Tbk di DKI Jakarta.

\section{Rumusan Masalah} berikut:

Berdasarkan latar belakang masalah, maka penelitian ini dapat dirumuskan sebagai

1. Apakah terdapat pengaruh langsung kompensasi terhadap keinginan berpindah?

2. Apakah terdapat pengaruh langsung lingkungan kerja terhadap keinginan berpindah?

3. Apakah terdapat pengaruh langsung kepuasan kerja terhadap keinginan berpindah?

4. Apakah terdapat pengaruh langsung kompensasi terhadap kepuasan kerja?

5. Apakah terdapat pengaruh langsung lingkungan kerja terhadap kepuasan kerja?

\section{Manfaat Penelitian}

Penelitian ini diharapkan dapat memberikan manfaat informasi bagi para pengelola perusahaan di sektor perbankan dalam upaya mengembangkan, meningkatkan dan memperbaiki kompensasi, lingkungan kerja, dan kepuasan kerja karyawan, serta keinginan berpindah karyawan.

\section{Kerangka Pemikiran}

Berdasarkan latar belakang dan landasan teori di atas, maka model penelitian pada penelitian ini dapat digambarkan sebagai berikut:

\section{Gambar 1. Konstelasi antar Variabel}

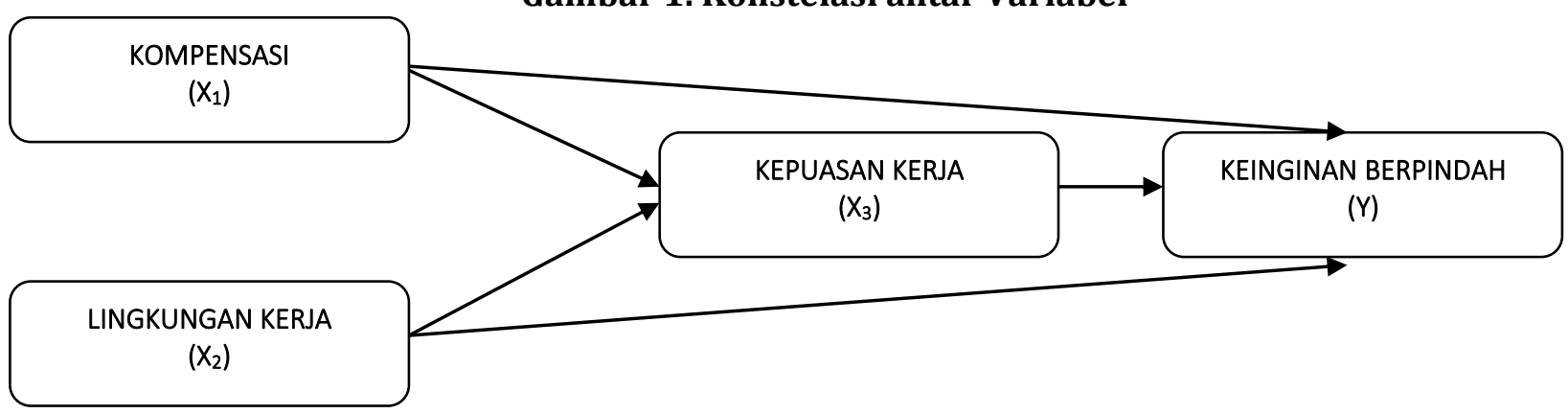


Berdasarkan kajian teoritik dan kerangka teoritik di atas maka hipotesis penelitian ini dirumuskan sebagai berikut:

$\mathrm{H}_{1}$ :Terdapat pengaruh positif yang signifikan antara kompensasi terhadap kepuasan kerja.

$\mathrm{H}_{2}$ :Terdapat pengaruh positif yang signifikan antara lingkungan kerja terhadap kepuasan kerja.

$\mathrm{H}_{3}$ :Terdapat pengaruh negatif yang signifikan antara kompensasi terhadap keinginan berpindah.

$\mathrm{H}_{4}$ :Terdapat pengaruh negatif yang signifikan antara lingkungan kerja terhadap keinginan berpindah.

$\mathrm{H}_{5}$ :Terdapat pengaruh negatif yang signifikan antara kepuasan kerja terhadap keinginan berpindah.

\section{METODE PENELITIAN}

Penelitian ini menggunakan pendekatan kuantitatif dengan menggunakan metode survei. Unit analisisnya adalah karyawan pada tiga kantor cabang Bank Panin di Jakarta Utara. Metode survei melibatkan pengumpulan data untuk menguji hipotesis atau menjawab pertanyaan orang tentang topik atau masalah tertentu. Sementara itu survei adalah instrumen untuk mengumpulkan data yang memaparkan satu atau lebih karakteristik suatu populasi. Dalam penelitian ini terdapat 5 (lima) variabel yang terdiri dari 3 (tiga) variabel bebas yaitu kompensasi, lingkungan kerja serta kepuasan kerja dan 1 (satu) variabel terikat yaitu keinginan berpindah.

Dalam penelitian ini, target penelitian yang ingin diteliti yaitu karyawan PT. Panin Bank Tbk yang ada di Jakarta dan berjumlah 80 orang.

\section{Instrumen Variabel Bebas/Eksogen}

\section{a. Kompensasi $\left(\mathrm{X}_{1}\right)$}

1) Definisi Konseptual

Kompensasi adalah penerimaan imbalan dalam bentuk finansial maupun non finansial atas hasil kerja seorang karyawan terhadap perusahaan.

\section{2) Definisi Operasional}

Kompensasi adalah keseluruhan karakteristik yang mengukur penerimaan imbalan dalam bentuk finansial maupun non finansial atas hasil kerja seorang karyawan terhadap perusahaan. Indikator-indikatornya adalah: (1) jaminan kesehatan; (2) gaji/upah dan (3) insentif.

\section{3) Kisi-kisi Instrumen}

\section{Tabel 3 Kisi-kisi Instrumen Variabel Kompensasi}

\begin{tabular}{|c|c|c|c|c|c|}
\hline \multirow[b]{2}{*}{ No } & \multirow[b]{2}{*}{ Dimensi } & \multicolumn{2}{|c|}{ Nomor Pertanyaan } & \multicolumn{2}{|c|}{ Jumlah } \\
\hline & & Positif & Negatif & $\begin{array}{l}\text { Sebelum } \\
\text { Penelitan }\end{array}$ & $\begin{array}{l}\text { Sesudah } \\
\text { Penelitian }\end{array}$ \\
\hline 1 & Gaji / Upah & $1,2,3,4,5,6$ & & 6 & 6 \\
\hline 2 & Insentif & $7,8,9$ & & 3 & 3 \\
\hline 3 & Jaminan Kesehatan & $10,11,12$ & & 3 & 2 \\
\hline & $\mathrm{Jumlah}$ & 12 & & 12 & 11 \\
\hline
\end{tabular}


Butir-butir pernyataan dihimpun dalam paket instrumen penelitian berupa kuesioner dalam bentuk skala lima alternatif jawaban: sangat setuju (skor 5), setuju (skor 4), netral (skor 3), tidak setuju (skor 2), dan sangat tidak setuju (skor 1).

4) Pengujian Validitas Instumen dan Perhitungan Reliabilitas

Sebelum digunakan untuk mengumpulkan data penelitian, terlebih dahulu kuesioner kompensasi diuji validitas dan reliabilitasnya. Kuesioner dalam bentuk skala peringkat/data interval, maka uji validitas menggunakan rumus korelasi Product Moment dari Pearson, dan reliabilitas menggunakan formula Alpha Cronbach. Perhitungan uji validitas dan reliabilitas menggunakan program SPSS versi 22.

\section{b. Lingkungan Kerja $\left(X_{2}\right)$}

1) Definisi Konseptual

Lingkungan kerja adalah keseluruhan atribut dan segala sesuatu yang terdapat di sekitar tempat kerja seorang karyawan yang dapat mempengaruhi dirinya dan pekerjaannya.

\section{2) Definisi Operasional}

Lingkungan kerja adalah keseluruhan karakteristik yang mengukur keseluruhan atribut dan segala sesuatu yang terdapat di sekitar tempat kerja seorang karyawan yang dapat mempengaruhi dirinya dan pekerjaannya. Indikator-indikatornya adalah: 1) cahaya/penerangan yang jelas, 2) suara yang tidak bising dan tenang, 3) keamanan di dalam bekerja, dan 4) tersedianya fasilitas kerja..

\section{3) Kisi-kisi Instrumen}

Tabel 4 Kisi-kisi Instrumen Variabel Lingkungan Kerja

\begin{tabular}{|c|c|c|c|c|c|}
\hline \multirow[b]{2}{*}{ No } & \multirow[b]{2}{*}{ Dimensi } & \multicolumn{2}{|c|}{ Nomor Pertanyaan } & \multicolumn{2}{|c|}{ Jumlah } \\
\hline & & Positif & $\begin{array}{c}\text { Nega } \\
\text { tif }\end{array}$ & $\begin{array}{l}\text { Sebelum } \\
\text { Penelitan }\end{array}$ & $\begin{array}{c}\text { Sesudah } \\
\text { Penelitian }\end{array}$ \\
\hline 1 & $\begin{array}{l}\text { Suara yang tidak bising dan } \\
\text { tenang }\end{array}$ & $1,2,3$ & & 3 & 3 \\
\hline 2 & Tersedianya fasilitas kerja & $4,5,6,7$ & & 4 & 4 \\
\hline 3 & $\begin{array}{l}\text { Cahaya/penerangan yang } \\
\text { jelas }\end{array}$ & $8,9,10$ & & 3 & 3 \\
\hline 4 & Keamanan di dalam bekerja & $11,12,13,14,15$ & & 5 & 3 \\
\hline & $\mathrm{Jumlah}$ & 15 & & 15 & 13 \\
\hline
\end{tabular}

Butir-butir pernyataan dihimpun dalam paket instrumen penelitian berupa kuesioner dalam bentuk skala lima alternatif jawaban: sangat setuju (skor 5), setuju (skor 4), netral (skor 3), tidak setuju (skor 2), dan sangat tidak setuju (skor 1).

\section{4) Pengujian Validitas Instumen dan Perhitungan Reliabilitas}

Sebelum digunakan untuk mengumpulkan data penelitian, terlebih dahulu kuesioner lingkungan kerja diuji validitas dan reliabilitasnya. Kuesioner dalam bentuk skala peringkat/data interval, maka uji validitas menggunakan rumus korelasi Product Moment dari Pearson, dan reliabilitas menggunakan formula Alpha Cronbach.Perhitungan uji validitas dan reliabilitas menggunakan program SPSS versi 22.

\section{c. Kepuasan Kerja $\left(\mathrm{X}_{3}\right)$}

\section{1) Definisi Konseptual}

Kepuasan kerja adalah kondisi psikologis karyawan yang mencerminkan perasaan positif terhadap pekerjaannya. 


\section{2) Definisi Operasional}

Kepuasan kerja adalah keseluruhan karakteristik yang mengukur kondisi psikologis karyawan yang mencerminkan perasaan positif terhadap pekerjaannya. Indikatorindikatornya adalah: (1) Pekerjaan itu sendiri; (2) Imbalan dari pekerjaan itu; (3) Supervisi dari atasan; (4) Rekan kerja, dan (5) Kesempatan promosi.

\section{3) Kisi-kisi Instrumen}

Tabel 5 Kisi-kisi Instrumen Variabel Kepuasan Kerja

\begin{tabular}{|c|l|c|c|c|c|}
\hline \multirow{2}{*}{ No } & \multirow{2}{*}{ Dimensi } & \multicolumn{2}{c|}{ Nomor Pertanyaan } & \multicolumn{2}{c|}{ Jumlah } \\
\cline { 3 - 6 } & & Positif & Negatif & $\begin{array}{c}\text { Sebelum } \\
\text { Penelitan }\end{array}$ & $\begin{array}{c}\text { Sesudah } \\
\text { Penelitian }\end{array}$ \\
\hline 1 & Rekan kerja & $1,2,3$ & & 3 & 3 \\
\hline 2 & Pekerjaan itu sendiri & $4,5,6$ & & 3 & 3 \\
\hline 3 & Supervisi dari atasan & $7,8,9,11$ & 10 & 5 & 5 \\
\hline 4 & Kesempatan promosi & $12,13,14$ & & 3 & 2 \\
\hline 5 & Imbalan dari pekerjaan itu & 15,17 & 16 & 3 & 2 \\
\hline \multicolumn{2}{r}{ J u m l a h } & 15 & 2 & 17 & 15 \\
\hline
\end{tabular}

Butir-butir pernyataan dihimpun dalam paket instrumen penelitian berupa kuesioner dalam bentuk skala lima alternatif jawaban: sangat setuju (skor 5), setuju (skor 4), netral (skor 3), tidak setuju (skor 2), dan sangat tidak setuju (skor 1).

\section{4) Pengujian Validitas Instumen dan Perhitungan Reliabilitas}

Sebelum digunakan untuk mengumpulkan data penelitian, terlebih dahulu kuesioner kepuasan kerja diuji validitas dan reliabilitasnya. Kuesioner dalam bentuk skala peringkat/data interval, maka uji validitas menggunakan rumus korelasi Product Moment dari Pearson, dan reliabilitas menggunakan formula Alpha Cronbach. Perhitungan uji validitas dan reliabilitas menggunakan program SPSS versi 22.

\section{A. Teknik Analisis Data}

1. Uji Prasyarat Analisis

\section{a. Uji Multikolinearitas}

Masalah-masalah yang mungkin akan timbul pada penggunaan persamaan regresi berganda adalah multikolinearitas, yaitu suatu keadaan yang variabel bebasnya berkorelasi dengan variabel bebas lainnya atau suatu variabel bebas merupakan fungsi linier dari variabel bebas lainnya. Adanya Multikolinearitas dapat dilihat dari tolerance value atau nilai variance inflation factor (VIF). Batas dari tolerance value dibawah 0,10 atau nilai VIF diatas 10, maka terjadi problem multikolinearitas (Umar 2010).

\section{b. Uji Heteroskedasitas}

Uji Heteroskedasitas bertujuan menguji apakah dalam model regresi terjadi ketidaksamaan variance dari residual satu pengamatan ke pengamatan yang lain. Model regresi yang baik adalah yang tidak terjadi heteroskedasitas. Metode yang dapat dipakai untuk mendeteksi gejala heterokedasitas antara lain: metode grafik, park glejser, rank spearman dan barlett.

Dalam penelitian ini metode yang digunakan untuk mendeteksi gejala heteroskedasitas dengan melihat grafik plot antara nilai prediksi varabel terikat (ZPRED) dengan residualnya (SRESID). Deteksi ada tidaknya heteroskedasitas dapat dilakukan dengan melihat ada tidaknya pola tertentu pada grafik scatterplot antara ZPRED adan SRESID dimana sumbu Y adalah Y yang telah diprediksi, dan sumbu X adalah residual (Y prediksi Y sesungguhnya) yang terletak di Studentized.

1) Jika ada titik-titik yang membentuk pola tertentu yang teratur maka mengidentifikasikan telah terjadi heterokedasitas. 
2) Jika tidak ada pola yang jelas, serta titik-titik menyebar di atas dan dibawah angka 0 pada sumbu Y, maka tidak terjadi heteroskedasitas (Supriyadi 2014).

\section{c. Uji Normalitas}

Uji Normalitas bertujuan untuk menguji apakah model regresi, variabel terikat dan variabel bebas keduanya mempunyai distribusi normal atau tidak. Model regresi yang baik adalah memiliki distribusi data normal atau mendekati normal.

Uji Normalitas dalam penelitian ini dilakukan dengan cara analisis grafik. Normalitas dapat dideteksi dengan melihat penyebaran data (titik) pada sumbu diagonal dari grafik atau dengan melihat histogram dari residualnya.

1) Jika data menyebar di sekitar garis diagonal dan mengikuti garis diagonal atau grafik histogramnya menunjukkan pola distribusi normal regresi memenuhi asumsi normalitas.

2) Jika data menyebar jauh dari garis diagonal dan atau tidak mengikuti arah garis diagonal atau grafik histogram tidak menunjukkan pola distribusi normal, maka model regresi tidak memenuhi asumsi normalitas.

Uji normalitas dilakukan dengan menggunakan metode one sample kolmogorov smirnov dimana nilai signifikansi (Asymp Sig 2-tailed) >0,05 dikatakan data berdistribusi normal dan sebaliknya data dikatakan berdistribusi tidak normal apabila signifikansi < 0,005 (Umar 2010).

\section{Uji Hipotesis}

\section{a. Regresi Berganda}

Analisis data dalam penelitian ini menggunakan analisis regresi yang bertujuan untuk mengetahui besarnya pengaruh beberapa variabel independen terhadap variabel dependen. Dalam penelitian ini analisis regresi yang dipakai adalah analisis regresi berganda di mana secara umum data hasil pengamatan $Y$ dipengaruhi oleh beberapa variabel bebas X1, X2, X3, ...., Xn. Sehingga rumus umum dari regresi berganda yang dikutip dalam Sugiyono (2017) yaitu :

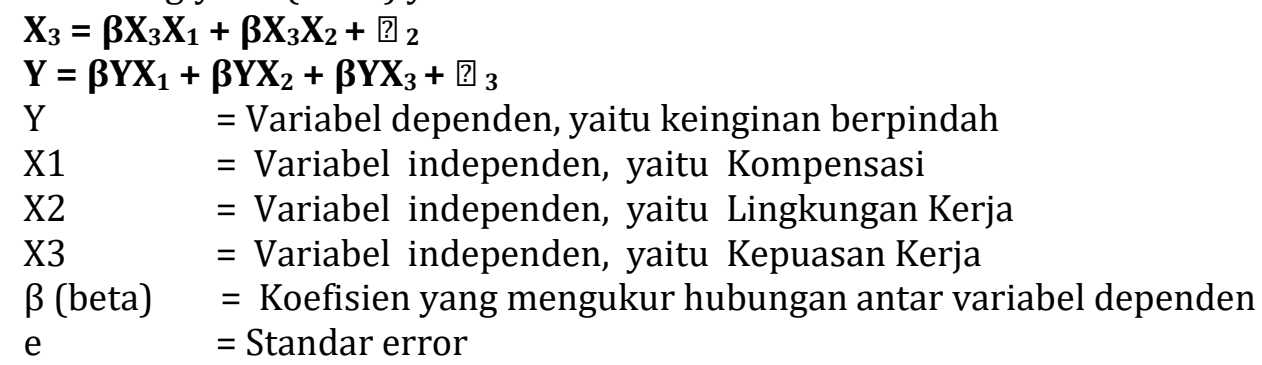

\section{b. Analisis Koefisien Determinasi $\left(\mathbf{R}^{2}\right)$}

Pada model linear berganda ini, akan dilihat besarnya kontribusi untuk variabel bebas secara bersama-sama terhadap variabel terikatnya dengan melihat besarnya koefisien determinasi totalnya $\left(\mathrm{R}^{2}\right)$. Jika $\left(\mathrm{R}^{2}\right)$ yang diperoleh mendekati 1 (satu) maka dapat dikatakan semakin kuat model tersebut menerangkan hubungan variabel bebas terhadap variabel terikat. Sebaliknya jika $\left(\mathrm{R}^{2}\right)$ makin mendekati 0 (nol) maka semakin lemah pengaruh variabel-variabel bebas terhadap variabel terikat (Supriyadi 2014).

\section{c. Uji t (Uji Parsial)}

Yaitu pengujian regresi secara terpisah atau parsial antar masing-masing variabel independen terhadap variabel dependen. Pengujian ini digunakan untuk mengetahui apakah masing-masing variabel bebasnya secara sendiri-sendiri berpengaruh secara signifikan terhadap variabel terikatnya. Dimana $\mathrm{T}_{\text {tabel }}>\mathrm{T}_{\text {hitung, }} \mathrm{H} 0$ diterima. Dan jika $\mathrm{T}_{\text {tabel }}<$ $\mathrm{T}_{\text {hitung, maka } \mathrm{H} 1 \text { diterima, begitupun jika sig > } \alpha}(0,05)$, maka H0 diterima H1 ditolak dan jika sig < $\alpha(0,05)$, maka H0 ditolak H1 diterima (Supriyadi 2014). 


\section{a. Hipotesis Statistik}

Hipotesis merupakan jawaban sementara yang kebenaranya akan diuji dalam penelitian. Adapun hipotesis dalam penelitian ini adalah:

a. $\mathrm{H}_{0}: \mathrm{X} 1=0$

$\mathrm{H}_{1}: \mathrm{X} 1 \neq 0$

b. $\mathrm{H}_{0}: \mathrm{X} 2=0$

$\mathrm{H}_{1}: \mathrm{X} 2 \neq 0$

c. $\mathrm{H}_{0}: \mathrm{X} 3=0$

$\mathrm{H}_{1}: \mathrm{X} 3 \neq 0$

d. $\mathrm{H}_{0}: \mathrm{X} 4=0$

$\mathrm{H}_{1}: \mathrm{X} 4 \neq 0$

e. $\mathrm{H}_{0}: \mathrm{X} 5=0$

$\mathrm{H}_{1}: \mathrm{X} 5 \neq 0$
Tidak terdapat pengaruh negatif antara kompensasi terhadap keinginan berpindah karyawan PT. Panin Bank Tbk di Jakarta.

Terdapat pengaruh negatif antara kompensasi terhadap keinginan berpindah karyawan PT. Panin Bank Tbk di Jakarta. Tidak terdapat pengaruh negatif antara lingkungan kerja terhadap keinginan berpindah karyawan PT. Panin Bank Tbk di Jakarta.

Terdapat pengaruh negatif antara lingkungan kerja terhadap keinginan berpindah karyawan PT. Panin Bank Tbk di Jakarta.

Tidak terdapat pengaruh negatif antara kepuasan kerja terhadap keinginan berpindah karyawan PT. Panin Bank Tbk di Jakarta.

Terdapat pengaruh negatif antara kepuasan kerja terhadap keinginan berpindah karyawan PT. Panin Bank Tbk di Jakarta.

Tidak terdapat pengaruh positif antara kompensasi terhadap kepuasan kerja karyawan PT. Panin Bank Tbk di Jakarta.

Terdapat pengaruh positif antara kompensasi terhadap kepuasan kerja karyawan PT. Panin Bank Tbk di Jakarta.

Tidak terdapat pengaruh positif antara lingkungan kerja terhadap kepuasan kerja karyawan PT. Panin Bank Tbk di Jakarta.

Terdapat pengaruh positif antara lingkungan kerja terhadap kepuasan kerja karyawan PT. Panin Bank Tbk di Jakarta.

\section{HASIL DAN PEMBAHASAN}

Kuesioner yang disebar sejumlah 80 eksemplar dengan hasil uji validitas dan relibilitas untuk setiap variabel dapat dilihat sebagai berikut:

Tabel 6

Uji validitas dan reliabilitas variabel Kompensasi

\begin{tabular}{cccccccccc}
\hline No. Butir & $\boldsymbol{\Sigma} \mathbf{X}_{\mathbf{i}}$ & $\boldsymbol{\Sigma} \mathbf{X}_{\mathbf{i}}{ }^{2}$ & $\boldsymbol{\Sigma} \mathbf{X}_{\mathbf{i}} \cdot \mathbf{X}_{\mathbf{t}}$ & $\boldsymbol{\Sigma} \mathbf{X}_{\mathbf{i}}{ }^{2}$ & $\boldsymbol{\Sigma} \mathbf{X}_{\mathbf{i}} \cdot \mathbf{X}_{\mathbf{t}}$ & $\boldsymbol{\Sigma} \mathbf{X}_{\mathbf{t}}{ }^{2}$ & $\mathbf{r}_{\text {hitung }}$ & $\mathbf{r}_{\text {tabel }}$ & Ket. \\
\hline 1 & 85 & 263 & 3381 & 22,17 & 85,83333 & 997,3667 & 0,577 & 0,361 & VALID \\
2 & 101 & 373 & 4059 & 32,97 & 143,5667 & 997,3667 & 0,792 & 0,361 & VALID \\
3 & 124 & 524 & 4852 & 11,47 & 44,93333 & 997,3667 & 0,420 & 0,361 & VALID \\
4 & 115 & 469 & 4543 & 28,17 & 84,83333 & 997,3667 & 0,506 & 0,361 & VALID \\
5 & 96 & 348 & 3815 & 40,80 & 93,4 & 997,3667 & 0,463 & 0,361 & VALID \\
6 & 104 & 384 & 4140 & 23,47 & 108,2667 & 997,3667 & 0,708 & 0,361 & VALID \\
7 & 125 & 529 & 4893 & 8,17 & 47,16667 & 997,3667 & 0,523 & 0,361 & VALID \\
8 & 104 & 384 & 4140 & 23,47 & 108,2667 & 997,3667 & 0,708 & 0,361 & VALID \\
9 & 123 & 517 & 4825 & 12,70 & 56,7 & 997,3667 & 0,504 & 0,361 & VALID \\
10 & 92 & 306 & 3654 & 23,87 & 87,46667 & 997,3667 & 0,567 & 0,361 & VALID \\
11 & 94 & 360 & 3781 & 65,47 & 136,9333 & 997,3667 & 0,536 & 0,361 & VALID \\
\hline
\end{tabular}


Dari perhitungan di atas menunjukkan bahwa butir tiap skor valid dan $r_{i i}$ sebesar 0,777 sehingga termasuk dalam kategori $(0,600$ - 0,799). Maka instrumen memiliki reliabilitas yang tinggi.

Hasil uji coba validitas dan reliabilitas untuk variabel lingkungan kerja terhadap jawaban dari kuesioner adalah sebagai berikut :

Tabel 7

Uji validitas dan reliabilitas variabel Linngkungan Kerja

\begin{tabular}{cccccccccc}
\hline No. & $\boldsymbol{\Sigma} \mathbf{X}_{\mathbf{i}}$ & $\boldsymbol{\Sigma} \mathbf{X}_{\mathbf{i}}{ }^{2}$ & $\begin{array}{c}\boldsymbol{\Sigma} \mathbf{X}_{\mathbf{i}} \cdot \\
\mathbf{X}_{\mathbf{t}}\end{array}$ & $\boldsymbol{\Sigma} \mathbf{X}_{\mathbf{i}}{ }^{2}$ & $\begin{array}{c}\boldsymbol{\Sigma} \mathbf{X}_{\mathbf{i}} \cdot \\
\mathbf{X}_{\mathbf{t}}\end{array}$ & $\boldsymbol{\Sigma} \mathbf{X}_{\mathbf{t}}{ }^{2}$ & $\mathbf{r}_{\text {hitung }}$ & $\mathbf{r}_{\text {tabel }}$ & Ket. \\
\hline 1 & 85 & 263 & 3969 & 22,17 & 93 & 1285,2 & 0,551 & 0,361 & VALID \\
2 & 101 & 373 & 4762 & 32,97 & 156,4 & 2402,8 & 0,760 & 0,361 & VALID \\
3 & 124 & 524 & 5708 & 11,47 & 53,6 & 2402,8 & 0,442 & 0,361 & VALID \\
4 & 115 & 469 & 5338 & 28,17 & 94 & 2402,8 & 0,494 & 0,361 & VALID \\
5 & 96 & 348 & 4476 & 40,80 & 98,4 & 2402,8 & 0,430 & 0,361 & VALID \\
6 & 104 & 384 & 4863 & 23,47 & 120,6 & 2402,8 & 0,694 & 0,361 & VALID \\
7 & 125 & 529 & 5756 & 8,17 & 56 & 2402,8 & 0,547 & 0,361 & VALID \\
9 & 104 & 384 & 4863 & 23,47 & 120,6 & 2402,8 & 0,694 & 0,361 & VALID \\
10 & 123 & 517 & 5672 & 12,70 & 63,2 & 2402,8 & 0,495 & 0,361 & VALID \\
13 & 94 & 306 & 4309 & 23,87 & 113,8 & 2402,8 & 0,650 & 0,361 & VALID \\
14 & 92 & 306 & 4309 & 23,87 & 113,8 & 2402,8 & 0,650 & 0,361 & VALID \\
15 & 113 & 433 & 5201 & 7,37 & 48,2 & 2402,8 & 0,495 & 0,361 & VALID \\
\hline
\end{tabular}

Dari perhitungan di atas menunjukkan bahwa butir tiap skor valid dan $r_{\mathrm{ii}}$ sebesar 0,810 sehingga termasuk dalam kategori $(0,800$ - 1,000). Maka instrumen memiliki reliabilitas yang sangat tinggi.

Hasil uji coba validitas dan reliabilitas untuk variabel kepuasan kerja terhadap jawaban dari kuesioner adalah sebagai berikut :

Tabel 8

Uji validitas dan reliabilitas variabel Kepuasan Kerja

\begin{tabular}{ccccccccc}
\hline$\Sigma \mathbf{X}_{\mathbf{i}}$ & $\Sigma \mathbf{X}_{\mathbf{i}}{ }^{2}$ & $\Sigma \mathbf{X}_{\mathbf{i}} \cdot \mathbf{X}_{\mathbf{t}}$ & $\Sigma \mathbf{X}_{\mathbf{i}}{ }^{2}$ & $\Sigma \mathbf{X}_{\mathbf{i}} \cdot \mathbf{X}_{\mathbf{t}}$ & $\Sigma \mathbf{X}_{\mathbf{t}^{2}}$ & $\mathbf{r}_{\text {hitung }}$ & $\mathbf{r}_{\text {tabel }}$ & Ket. \\
\hline 85 & 263 & 4603 & 22,17 & 106,5 & 1712,7 & 0,547 & 0,361 & VALID \\
101 & 373 & 5517 & 32,97 & 174,1 & 1712,7 & 0,733 & 0,361 & VALID \\
124 & 524 & 6622 & 11,47 & 62,4 & 1712,7 & 0,445 & 0,361 & VALID \\
115 & 469 & 6198 & 28,17 & 114,5 & 1712,7 & 0,521 & 0,361 & VALID
\end{tabular}




\begin{tabular}{ccccccccc}
96 & 348 & 5182 & 40,80 & 103,6 & 1712,7 & 0,392 & 0,361 & VALID \\
104 & 384 & 5635 & 23,47 & 133,4 & 1712,7 & 0,665 & 0,361 & VALID \\
125 & 529 & 6679 & 8,17 & 66,5 & 1712,7 & 0,562 & 0,361 & VALID \\
104 & 384 & 5635 & 23,47 & 133,4 & 1712,7 & 0,665 & 0,361 & VALID \\
123 & 517 & 6577 & 12,70 & 70,3 & 1712,7 & 0,477 & 0,361 & VALID \\
92 & 306 & 4997 & 23,87 & 130,2 & 1712,7 & 0,644 & 0,361 & VALID \\
104 & 384 & 5157 & 23,47 & 184,4 & 1712,7 & 0,551 & 0,361 & VALID \\
104 & 384 & 4997 & 23,47 & 130,2 & 1712,7 & 0,644 & 0,361 & VALID \\
113 & 433 & 6040 & 7,37 & 62,3 & 1712,7 & 0,555 & 0,361 & VALID \\
102 & 370 & 5544 & 23,20 & 148,2 & 1712,7 & 0,743 & 0,361 & VALID \\
117 & 473 & 6282 & 16,70 & 92,7 & 1712,7 & 0,548 & 0,361 & VALID \\
\hline
\end{tabular}

Dari perhitungan di atas menunjukkan bahwa butir tiap skor valid dan $\mathrm{r}_{\text {ii }}$ sebesar 0,844 sehingga termasuk dalam kategori $(0,800$ - 1,000). Maka instrumen memiliki reliabilitas yang sangat tinggi.

Hasil uji coba validitas dan reliabilitas untuk variabel keinginan berpindah terhadap jawaban dari kuesioner adalah sebagai berikut :

Tabel 9

Uji validitas dan reliabilitas variabel Keinginan Berpindah

\begin{tabular}{|c|c|c|c|c|c|c|c|c|c|}
\hline No.Butir & $\sum \mathbf{X}_{\mathbf{i}}$ & $\sum \mathbf{X}_{\mathbf{i}}^{2}$ & $\begin{array}{c}\sum \mathbf{X}_{\mathbf{i}} \\
\mathbf{X}_{\mathbf{t}}\end{array}$ & $\sum \mathbf{X}_{\mathbf{i}}^{2}$ & $\sum \mathbf{X}_{\mathbf{i}} \cdot \mathbf{X}_{\mathbf{t}}$ & $\Sigma X_{t^{2}}$ & $\mathbf{r}_{\text {hitung }}$ & $\mathbf{r}_{\text {tabel }}$ & Ket. \\
\hline 1 & 85 & 263 & 3647 & 22,17 & 91,16667 & 1196,167 & 0,560 & 0,361 & VALID \\
\hline 2 & 101 & 373 & 4377 & 32,97 & 151,8333 & 1196,167 & 0,765 & 0,361 & VALID \\
\hline 3 & 124 & 524 & 5236 & 11,47 & 48,66667 & 1196,167 & 0,416 & 0,361 & VALID \\
\hline 4 & 115 & 469 & 4900 & 28,17 & 89,16667 & 1196,167 & 0,486 & 0,361 & VALID \\
\hline 5 & 96 & 348 & 4115 & 40,80 & 99 & 1196,167 & 0,448 & 0,361 & VALID \\
\hline 6 & 104 & 384 & 4468 & 23,47 & 117,3333 & 1196,167 & 0,700 & 0,361 & VALID \\
\hline 7 & 125 & 529 & 5283 & 8,17 & 53,83333 & 1196,167 & 0,545 & 0,361 & VALID \\
\hline 8 & 104 & 384 & 4468 & 23,47 & 117,3333 & 1196,167 & 0,700 & 0,361 & VALID \\
\hline 9 & 123 & 517 & 5206 & 12,70 & 60,5 & 1196,167 & 0,491 & 0,361 & VALID \\
\hline 10 & 92 & 306 & 3960 & 23,87 & 111,3333 & 1196,167 & 0,659 & 0,361 & VALID \\
\hline 13 & 94 & 360 & 4077 & 65,47 & 144,6667 & 1196,167 & 0,517 & 0,361 & VALID \\
\hline 14 & 92 & 306 & 3960 & 23,87 & 111,3333 & 1196,167 & 0,659 & 0,361 & VALID \\
\hline
\end{tabular}




\section{Pengujian Persyaratan Analisis Data}

\section{a. Uji Multikolinearitas}

Uji Multikolinieritas digunakan untuk menguji apakah antara variabel bebas memiliki hubungan yang sempurna atau tidak. Syarat diterimanya model regresi ganda apabila antara variabel bebas tidak mengandung korelasi yang sempurna. Pengujian multikolinieritas dapat dilihat dari nilai variance inflance factor (VIF) berdasarkan hasil output SPSS. Apabila nilai $\mathrm{VIF}<10$ dan mendekati 1 dapat disimpulkan bahwa asumsi adanya multikolinieritas ditolak.

\section{Tabel 10}

Coefficients ${ }^{\mathrm{a}}$

\begin{tabular}{|c|c|c|c|c|c|c|c|}
\hline \multirow[t]{3}{*}{ Model } & \multicolumn{2}{|c|}{$\begin{array}{l}\text { Unstandardized } \\
\text { Coefficients }\end{array}$} & \multirow{3}{*}{$\begin{array}{c}\text { Standardized } \\
\text { Coefficients } \\
\text { Beta }\end{array}$} & \multirow[t]{3}{*}{$\mathrm{T}$} & \multirow[t]{3}{*}{ Sig. } & \multicolumn{2}{|c|}{$\begin{array}{l}\text { Collinearity } \\
\text { Statistics }\end{array}$} \\
\hline & B & Std. & & & & Tolerance & VIF \\
\hline & & Error & & & & & \\
\hline \multirow{4}{*}{$\begin{array}{l}\text { (Constant) } \\
\text { X1_Kompensasi } \\
\text { X2_Lingkungan_Kerja } \\
\text { X3_Kepuasan_Kerja }\end{array}$} & 75.023 & 4.576 & & 16.395 & .000 & & \\
\hline & -.300 & .089 & -.334 & -3.379 & .001 & .791 & 1.265 \\
\hline & -.214 & .088 & -.242 & -2.425 & .018 & .774 & 1.291 \\
\hline & -.188 & .077 & -.268 & -2.430 & .017 & .633 & 1.581 \\
\hline
\end{tabular}

a. Dependent Variable: Y_Keinginan_Berpindah

Berdasarkan hasil penelitian diperoleh nilai VIF untuk variabel Kompensasi sebesar 1.265, untuk variabel Lingkungan Kerja sebesar 1.291 dan untuk variabel Kepuasan Kerja sebesar 1.581. Ketiga nilai VIF dari variabel di atas $<10$ yang berarti bahwa model regresi tidak mengandung multikolineritas.

\section{b. Uji Heteroskedasitas}

Hasil dari uji heteroskedasitas dapat dilihat pada gambar 2 (Scatterplot) dibawah ini:

\section{Gambar 2}

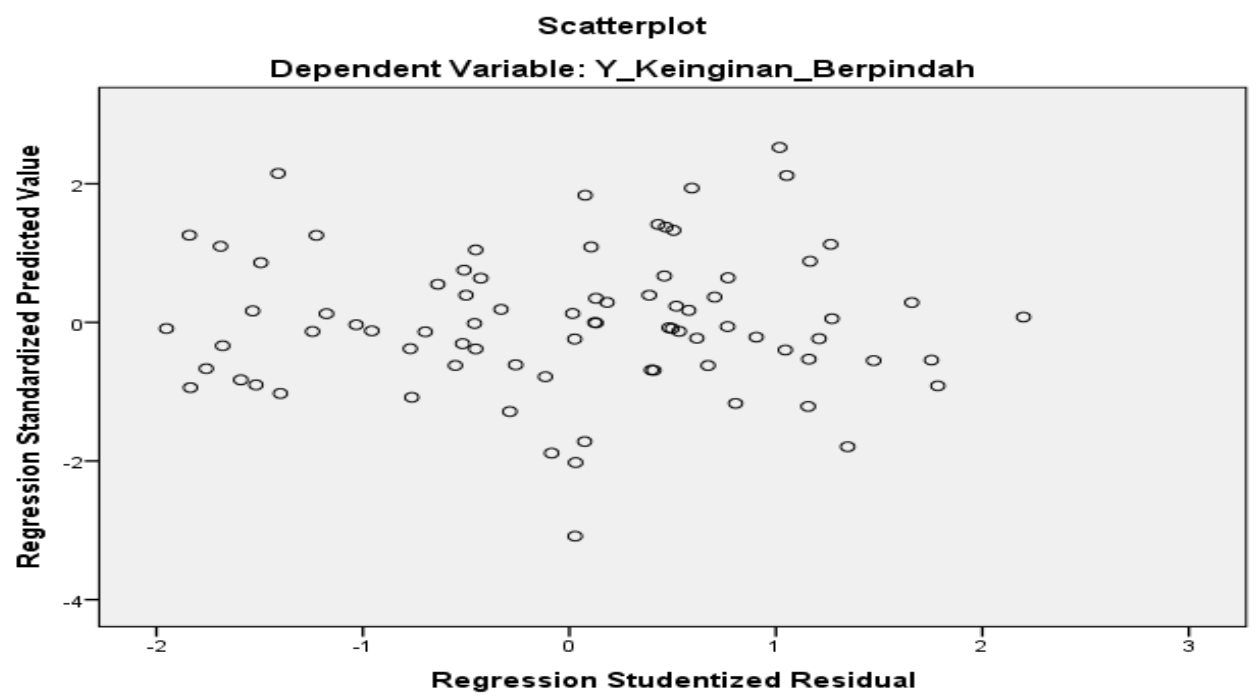

Hasil pengamatan dengan menggunakan grafik Scatterplot dapat diketahui bahwa 
terlihat pola yang menyebar dibawah dan di atas angka nol sumbu $\mathrm{Y}$, hali ini mengindikasikan bahwa tidak terjadi heterokedasitas.

\section{c. Uji Normalitas}

Model regresi yang baik adalah memiliki distribusi data normal atau mendekati normal. Metode yang dapat dipakai untuk normalitas antara lain analisis grafik dan analisis statistik. Uji normalitas dalam penelitian ini dilakukan dengan cara analisis grafik. Normalitas dapat dideteksi dengan melihat penyebaran data (titik) pada sumbu diagonal dari grafik atau dengan melihat histogram dari residualnya. Model regresi yang baik adalah memiliki distribusi data normal atau mendekati normal. Metode yang dapat dipakai untuk normalitas antara lain: analisis grafik dan analisis statistik. Uji normalitas dalam penelitian ini dilakukan dengan cara analisis grafik. Normalitas dapat dideteksi dengan melihat penyebaran data (titik) pada sumbu diagonal dari grafik atau dengan melihat histogram dari residualnya.

\section{Gambar 3 Normal P-P Plot}

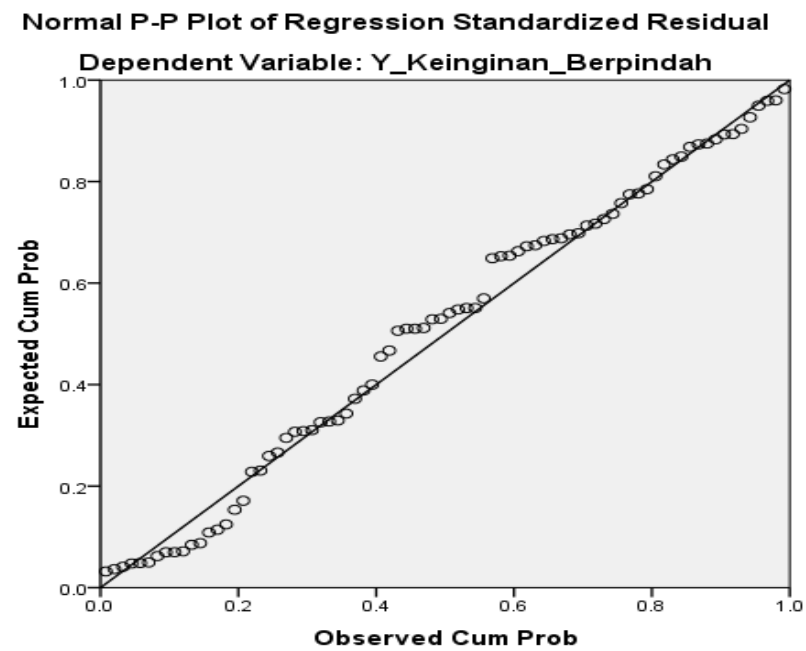

Dari gambar di atas dapat dilihat pada normal probability plot bahwa data menyebar di sekitar garis diagonal, dengan demikian menunjukkan bahwa data-data pada variabel penelitian berdistribusi normal. Sedangkan pada grafik Histogram didapatkan garis kurva yang normal, yang juga menunjukkan data yang diteliti di atas berdistribusi normal.

\section{Gambar 4 Histogram}

Histogram

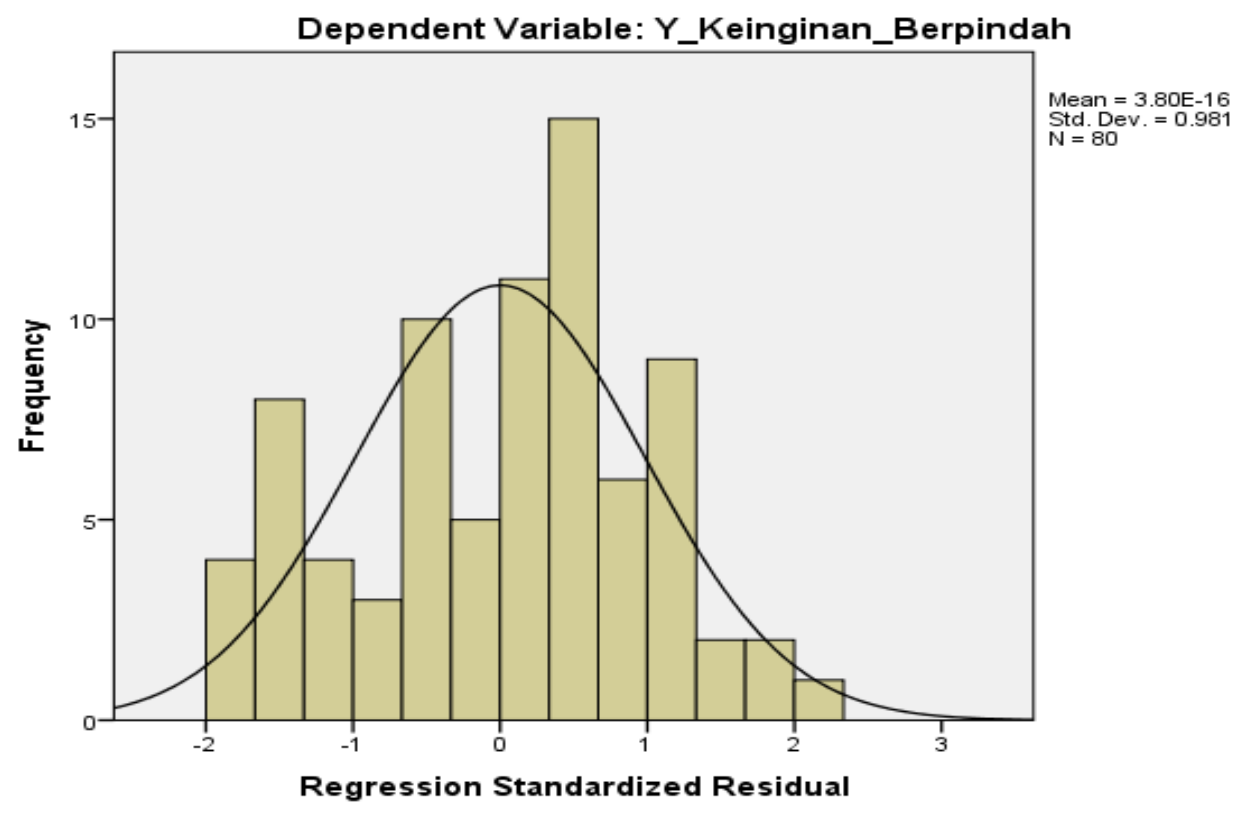


Tabel 11

One-Sample Kolmogorov-Smirnov Test

\begin{tabular}{llr}
\hline & & $\begin{array}{r}\text { Unstandardiz } \\
\text { ed Residual }\end{array}$ \\
\hline $\mathrm{N}$ & Mean & 80 \\
Normal Parameters ${ }^{\mathrm{a}, \mathrm{b}}$ & Std. & .0000000 \\
& Deviation & 3.35365883 \\
& Absolute & .089 \\
Most Extreme Differences & Positive & .068 \\
& Negative & -.089 \\
Kolmogorov-Smirnov Z & & .798 \\
Asymp. Sig. (2-tailed) & & .548 \\
\hline
\end{tabular}

a. Test distribution is Normal.

b. Calculated from data.

Berdasarkan hasil dari tabel 11 dapat diketahui bahwa nilai signifikansi (asymp) sebesar 0.548. Berdasarkan dari hasil tersebut dapat disimpulkan bahwa data berdistribusi normal karena berada di atas taraf signifikansi (0.05).

\section{Pengujian Hipotesis}

Pada uji hipotesa ini akan dilakukan dua tahap dalam melakukan analisis jalur yaitu tahap pertama untuk melihat pengaruh antara variabel independent yang terdiri dari: variabel kompensasi dan lingkungan kerja terhadap variabel dependent yaitu kepuasan kerja. Tahap kedua yang akan dilakukan pada uji hipotesa ini adalah melihat pengaruh antara variabel independen yang terdiri dari: variabel kompensasi, lingkungan kerja dan kepuasan kerja terhadap variabel dependent yaitu keinginan berpindah.

\section{Pengaruh Kompensasi dan Lingkungan Kerja terhadap Kepuasan Kerja}

\section{a. Persamaan Regresi Berganda}

Pada tahapan ini akan melihat pengaruh antara variabel independent yang terdiri dari: variabel kompensasi dan lingkungan kerja terhadap variabel dependent yaitu kepuasan kerja dengan melihat nilai pada tabel 12 dibawah ini:

\section{Tabel 12}

\section{Coefficients $^{\mathrm{a}}$}

\begin{tabular}{|c|c|c|c|c|c|c|}
\hline \multirow[t]{2}{*}{ Model } & \multicolumn{2}{|c|}{$\begin{array}{l}\text { Unstandardized } \\
\text { Coefficients }\end{array}$} & $\begin{array}{c}\text { Standardized } \\
\text { Coefficients }\end{array}$ & & $\mathrm{t}$ & Sig. \\
\hline & $\mathrm{B}$ & Std. Error & Beta & & & \\
\hline (Constant) & 9.828 & 6.654 & & & 1.477 & .144 \\
\hline 1 X1_Kompensasi & .494 & .118 & & .385 & 4.191 & .000 \\
\hline X2_Lingkungan_Kerja & .514 & .116 & & .407 & 4.421 & .000 \\
\hline
\end{tabular}

a. Dependent Variable: X3_Kepuasan_Kerja

Berdasarkan data di atas, persamaan struktural 1 sebagai berikut: 


$$
X_{3}=0.494 X_{1}+0.514 X_{2}+9.828
$$

Persamaan struktural 1 tersebut memiliki pengertian apabila variabel lingkungan kerja dan kompensasi memiliki nilai 0 , maka nilai variabel kepuasan kerja akan bernilai 9.828. Pengertian kedua, apabila variabel lain memiliki nilai 0 dan variabel kompensasi mengalami kenaikan sebesar 1 satuan, maka nilai variabel kepuasan kerja akan mengalami kenaikan sebesar 0.494. Pengertian ketiga, apabila variabel lain memiliki nilai 0 dan variabel lingkungan kerja mengalami kenaikan sebesar 1 satuan, maka nilai variabel kepuasan kerja akan mengalami kenaikan sebesar 0.514 .

\section{b. Koefisien Determinasi Struktural}

Tabel 13

Model Summary

\begin{tabular}{lrrrr}
\hline Model & R & R Square & $\begin{array}{c}\text { Adjusted R } \\
\text { Square }\end{array}$ & $\begin{array}{r}\text { Std. Error of } \\
\text { the Estimate }\end{array}$ \\
\hline 1 & $.606^{\mathrm{a}}$ & .367 & .351 & 5.042 \\
\hline
\end{tabular}

a. Predictors: (Constant), X2_Lingkungan_Kerja,

\section{X1_Kompensasi}

Berdasarkan tabel 13 di atas menunjukkan hasil koefisien determinasi antara variabel independent yang terdiri dari: variabel lingkungan kerja dan kompensasi terhadap variabel dependent yaitu kepuasan kerja. Hasil R Square sebesar 0.367 atau $36.7 \%$ yang artinya adalah pengaruh kompensasi dan lingkungan kerja terhadap kepuasan kerja karyawan PT Panin Bank Tbk Jakarta sebesar 36,7\% sedangkan sisanya sebesar 63.3\% dipengaruhi oleh faktor-faktor lain diluar penelitian ini. Sedangkan untuk melihat pengaruh variabel independen kompensasi dan lingkungan kerja terhadap kepuasan kerja secara parsial dapat dilihat pada nilai beta atau Standardized Coefficients pada tabel dengan menggunakan uji t.

\section{c. Uji t (Uji Parsial)}

Uji t digunakan untuk menguji pengaruh variabel independent dalam menerangkan keberadaan dari variabel dependent. Perhitungan statistik disebut signifikan apabila uji statistiknya berada dalam daerah Ho ditolak, sebaliknya disebut tidak signifikan apabila nilai uji statistiknya berada dalam daerah dimana Ho diterima. Jika nilai signifikansi $<0,05$ maka dapat dikatakan bahwa terdapat pengaruh antara variabel independent terhadap variabel dependent.

Tabel 14

Coefficients ${ }^{\mathrm{a}}$

\begin{tabular}{|c|c|c|c|c|c|c|}
\hline \multirow[t]{2}{*}{ Model } & \multicolumn{2}{|c|}{$\begin{array}{c}\text { Unstandardized } \\
\text { Coefficients }\end{array}$} & $\begin{array}{c}\text { Standardized } \\
\text { Coefficients }\end{array}$ & & $\mathrm{t}$ & Sig. \\
\hline & $\mathrm{B}$ & Std. Error & Beta & & & \\
\hline (Constant) & 9.828 & 6.654 & & & 1.477 & .144 \\
\hline 1 X1_Kompensasi & .494 & .118 & & .385 & 4.191 & .000 \\
\hline X2_Lingkungan_Kerja & .514 & .116 & & .407 & 4.421 & .000 \\
\hline
\end{tabular}

a. Dependent Variable: X3_Kepuasan_Kerja 
Hipotesis 4:

$\mathrm{H}_{0}: \mathrm{X} 4=0$

$\mathrm{H}_{1}: \mathrm{X} 4 \neq 0$

Tidak terdapat pengaruh positif antara kompensasi terhadap kepuasan kerja karyawan PT. Panin Bank Tbk di Jakarta.

Terdapat pengaruh positif antara kompensasi terhadap kepuasan kerja karyawan PT. Panin Bank Tbk di Jakarta.

Berdasarkan tabel di atas diperoleh nilai sig $0.000<0.05$, sehingga Ho ditolak dan H1 diterima. Tetapi mempunyai pengaruh yang positif dengan nilai koefisien B sebesar 0.494. Dengan demikian dapat dikatakan bahwa terdapat pengaruh positif secara signifikan kompensasi terhadap kepuasan kerja.

\section{Hipotesis 5:}

$\mathrm{H}_{0}: \mathrm{X} 5=0$

Tidak terdapat pengaruh positif antara lingkungan kerja terhadap kepuasan kerja karyawan PT. Panin Bank Tbk di Jakarta.

$\mathrm{H}_{1}: \mathrm{X} 5 \neq 0$

Terdapat pengaruh positif antara lingkungan kerja terhadap kepuasan kerja karyawan PT. Panin Bank Tbk di Jakarta.

Berdasarkan tabel di atas diperoleh nilai sig $0.000<0.05$, sehingga Ho ditolak dan H1 diterima dan mempunyai pengaruh yang positif dengan nilai koefisien B sebesar 0.514. Dengan demikian dapat dikatakan bahwa terdapat pengaruh positif secara signifikan lingkungan kerja terhadap kepuasan kerja.

\section{Pengaruh Kompensasi, Lingkungan Kerja dan Kepuasan Kerja terhadap Keinginan Berpindah \\ a. Persamaan Regresi Berganda}

Pada tahapan ini akan melihat pengaruh antara variabel independent yang terdiri dari: variabel kompensasi, lingkungan kerja dan kepuasan kerja terhadap variabel dependent yaitu keinginan berpindah dengan melihat nilai pada tabel 4.14 dibawah ini:

Tabel 15

Coefficients ${ }^{a}$

\begin{tabular}{llrrrrr}
\hline Model & \multicolumn{2}{c}{ Unstandardized } & \multicolumn{2}{c}{$\begin{array}{c}\text { Standardized } \\
\text { Coefficients }\end{array}$} & t & Sig. \\
& & B & Std. Error & Beta & & \\
\hline \multirow{2}{*}{1} & (Constant) & 75.023 & 4.576 & & 16.395 & .000 \\
& X1_Kompensasi & -.300 & .089 & -.334 & -3.379 & .001 \\
& X2_Lingkungan_Kerja & -.214 & .088 & -.242 & -2.425 & .018 \\
& X3_Kepuasan_Kerja & -.188 & .077 & -.268 & -2.430 & .017 \\
\hline
\end{tabular}

a. Dependent Variable: Y_Keinginan_Berpindah

Berdasarkan data di atas, persamaan struktural 2 sebagai berikut:

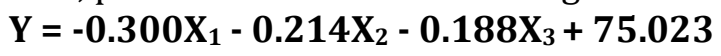

Persamaan struktural 2 tersebut memiliki pengertian apabila variabel kompensasi, lingkungan kerja dan kepuasan kerja memiliki nilai 0, maka nilai variabel keinginan berpindah akan bernilai 75.023. Pengertian kedua, apabila variabel lain memiliki nilai 0 dan variabel kompensasi mengalami kenaikan sebesar 1 satuan, maka nilai variabel keinginan berpindah akan mengalami kenaikan sebesar -0.300 . Pengertian ketiga, apabila variabel lain memiliki nilai 0 dan variabel lingkungan kerja mengalami kenaikan sebesar 1 satuan, maka nilai variabel keinginan berpindah akan mengalami kenaikan sebesar

-0.214. Pengertian 
keempat, apabila variabel lain memiliki nilai 0 dan variabel kepuasan kerja mengalami kenaikan sebesar 1 satuan, maka nilai variabel keinginan berpindah akan mengalami kenaikan sebesar -0.188 .

\section{b. Koefisien Determinasi}

Tabel 16

Model Summary

\begin{tabular}{|c|c|c|c|c|}
\hline Model & $\mathrm{R}$ & R Square & $\begin{array}{l}\text { Adjusted R } \\
\text { Square }\end{array}$ & $\begin{array}{l}\text { Std. Error of } \\
\text { the Estimate }\end{array}$ \\
\hline 1 & $.643^{a}$ & .413 & .390 & 3.419 \\
\hline
\end{tabular}

Berdasarkan tabel 16 di atas menunjukkan hasil koefisien determinasi antara variabel independent yang terdiri dari: variabel kompensasi, lingkungan kerja dan kepuasan kerja terhadap variabel dependent yaitu keinginan berpindah. Hasil R Square sebesar 0.413 atau $41.3 \%$ yang artinya adalah pengaruh kompensasi, lingkungan kerja dan kepuasan kerja terhadap keinginan berpindah karyawan PT Panin Bank Tbk Jakarta sebesar 41,3\% sedangkan sisanya sebesar $58.7 \%$ dipengaruhi oleh faktor-faktor lain diluar penelitian ini. Sedangkan untuk melihat pengaruh variabel independen kompensasi, lingkungan kerja dan kepuasan kerja terhadap keinginan berpindah secara parsial dapat dilihat pada nilai beta atau Standardized Coefficients pada tabel dengan menggunakan uji t.

\section{c. Uji t (Uji Parsial)}

Uji t digunakan untuk menguji pengaruh variabel independent dalam menerangkan keberadaan dari variabel dependent. Perhitungan statistik disebut signifikan apabila uji statistiknya berada dalam daerah Ho ditolak, sebaliknya disebut tidak signifikan apabila nilai uji statistiknya berada dalam daerah dimana H0 diterima. Jika nilai signifikansi $<0,05$ maka dapat dikatakan bahwa terdapat pengaruh antara variabel independent terhadap variabel dependent.

Tabel 17

Coefficients $^{\mathrm{a}}$

\begin{tabular}{|c|c|c|c|c|c|c|}
\hline \multirow[t]{2}{*}{ Model } & \multicolumn{2}{|c|}{$\begin{array}{c}\text { Unstandardized } \\
\text { Coefficients }\end{array}$} & \multirow{2}{*}{\multicolumn{2}{|c|}{$\begin{array}{c}\text { Standardized } \\
\text { Coefficients }\end{array}$}} & \multirow[t]{2}{*}{$\mathrm{t}$} & \multirow[t]{2}{*}{ Sig. } \\
\hline & $\mathrm{B}$ & Std. Error & & & & \\
\hline (Constant) & 75.023 & 4.576 & & & 16.395 & .000 \\
\hline X1_Kompensasi & -.300 & .089 & & -.334 & -3.379 & .001 \\
\hline${ }^{1}$ X2_Lingkungan_Kerja & -.214 & .088 & & -.242 & -2.425 & .018 \\
\hline X3_Kepuasan_Kerja & -.188 & .077 & & -.268 & -2.430 & .017 \\
\hline
\end{tabular}

a. Dependent Variable: Y_Keinginan_Berpindah

Hipotesis 1:

$\mathrm{H}_{0}: \mathrm{X} 1=0$
Tidak terdapat pengaruh negatif antara kompensasi terhadap keinginan berpindah karyawan PT. Panin Bank Tbk di Jakarta. 
$\mathrm{H}_{1}: \mathrm{X} 1 \neq 0$

Terdapat pengaruh negatif antara kompensasi terhadap keinginan berpindah karyawan PT. Panin Bank Tbk di Jakarta.

Berdasarkan tabel di atas diperoleh nilai sig $0.001<0.05$, sehingga Ho ditolak dan H1 diterima dan mempunyai pengaruh yang negatif dengan nilai koefisien B sebesar -0.300 . Dengan demikian dapat dikatakan bahwa terdapat pengaruh negatif secara signifikan kompensasi terhadap keinginan berpindah.

\section{Hipotesis 2:}

$\mathrm{H}_{0}: \mathrm{X} 2=0$

$\mathrm{H}_{1}: \mathrm{X} 2 \neq 0$

Tidak terdapat pengaruh negatif antara lingkungan kerja terhadap keinginan berpindah karyawan PT. Panin Bank Tbk di Jakarta.

Terdapat pengaruh negatif antara lingkungan kerja terhadap keinginan berpindah karyawan PT. Panin Bank Tbk di Jakarta.

Berdasarkan tabel di atas diperoleh nilai sig $0.018<0.05$, sehingga H0 ditolak dan H1 diterima dan mempunyai pengaruh yang negatif dengan nilai koefisien B sebesar -0.214 . Dengan demikian dapat dikatakan bahwa terdapat pengaruh negatif secara signifikan lingkungan kerja terhadap keinginan berpindah.

\section{Hipotesis 3:}

$\mathrm{H} 0: \mathrm{X} 3=0$

Tidak terdapat pengaruh negatif antara kepuasan kerja terhadap

$\mathrm{H} 1: \mathrm{X} 3 \neq 0$ keinginan berpindah karyawan PT. Panin Bank Tbk di Jakarta.

Terdapat pengaruh negatif antara kepuasan kerja terhadap keinginan berpindah karyawan PT. Panin Bank Tbk di Jakarta.

Berdasarkan tabel di atas diperoleh nilai sig $0.017<0.05$, sehingga $\mathrm{H} 0$ ditolak dan $\mathrm{H} 1$ diterima dan mempunyai pengaruh yang negatif dengan nilai koefisien B sebesar -0.188 . Dengan demikian dapat dikatakan bahwa terdapat pengaruh negatif secara signifikan kepuasan kerja terhadap keinginan berpindah.

\section{Perhitungan Pengaruh Analisis Jalur}

\section{a. Pengaruh Langsung (Direct Effect)}

Untuk menghitung pengaruh langsung, digunakan formula sebagai berikut:

- Pengaruh variabel kompensasi terhadap keinginan berpindah.

$$
\mathrm{X}_{1} \rightarrow \mathrm{Y}=-0.300
$$

- Pengaruh variabel lingkungan kerja terhadap keinginan berpindah

$$
\mathrm{X}_{2} \rightarrow \mathrm{Y}=-0.214
$$

- Pengaruh variabel kepuasan kerja terhadap keinginan berpindah.

$$
\mathrm{X}_{3} \rightarrow \mathrm{Y}=-0.188
$$

\section{b. Pengaruh Tidak Langsung (Indirect Effect)}

Untuk menghitung pengaruh tidak langsung, digunakan formula sebagai berikut:

- Pengaruh variabel kompensasi terhadap keinginan berpindah melalui kepuasan kerja.

$$
\mathrm{X}_{1} \rightarrow \mathrm{X}_{3} \rightarrow \mathrm{Y}=(0.494 \mathrm{x}-0.188)=-0.092
$$

- Pengaruh variabel lingkungan kerja terhadap keinginan berpindah melalui kepuasan kerja.

$$
\mathrm{X}_{2} \rightarrow \mathrm{X}_{3} \rightarrow \mathrm{Y}=(0.514 \mathrm{x}-0.188)=-0.096
$$

\section{c. Pengaruh Total (Total Effect)}

- Pengaruh variabel kompensasi terhadap keinginan berpindah. $\left(X_{1} \rightarrow Y\right)+\left(X_{1} \rightarrow X_{3} \rightarrow Y\right)=(-0.300-0.092)=-0.392$

- Pengaruh variabel lingkungan kerja terhadap keinginan berpindah 


$$
\left(\mathrm{X}_{2} \rightarrow \mathrm{Y}\right)+\left(\mathrm{X}_{2} \rightarrow \mathrm{X}_{3} \rightarrow \mathrm{Y}\right)=(-0.214-0.096)=-0.310
$$

- Pengaruh variabel kepuasan kerja terhadap keinginan berpindah. $\mathrm{X}_{3} \rightarrow \mathrm{Y}=-0.188$

\section{Uji Hipotesis}

Dalam penelitian ini yang melibatkan 80 orang responden, memberikan informasi mengenai pengaruh dari variabel kompensasi, lingkungan kerja serta kepuasan kerja terhadap keinginan berpindah karyawan PT Panin Bank Tbk di Jakarta, maka selanjutnya perlu dibahas eksistensi masing-masing variabel sebagai berikut:

\section{a. $\mathrm{H}_{\mathbf{1}}$ Pengaruh antara Kompensasi terhadap Keinginan Berpindah}

Berdasarkan tabel uji $t$ diperoleh nilai sig nilai sig $0.001<0.05$, sehingga H0 ditolak dan $\mathrm{H} 1$ diterima dan mempunyai pengaruh yang negatif dengan nilai koefisien B sebesar -0.300. Dengan demikian dapat dikatakan bahwa terdapat pengaruh negatif secara signifikan kompensasi terhadap keinginan berpindah.

b. $\mathrm{H}_{2}$ Pengaruh antara Lingkungan Kerja terhadap Keinginan Berpindah

Berdasarkan tabel uji t diperoleh nilai sig $0.018<0.05$, sehingga Ho ditolak dan H1 diterima dan mempunyai pengaruh yang negatif dengan nilai koefisien B sebesar 0.214. Dengan demikian dapat dikatakan bahwa terdapat pengaruh negatif secara signifikan lingkungan kerja terhadap keinginan berpindah.

\section{c. $\mathbf{H}_{3}$ Pengaruh antara Kepuasan Kerja terhadap Keinginan Berpindah}

Berdasarkan tabel uji t diperoleh nilai sig $0.017<0.05$, sehingga Ho ditolak dan H1 diterima dan mempunyai pengaruh yang negatif dengan nilai koefisien B sebesar 0.188. Dengan demikian dapat dikatakan bahwa terdapat pengaruh negatif secara signifikan kepuasan kerja terhadap keinginan berpindah.

\section{d. $\mathrm{H}_{4}$ Pengaruh antara Kompensasi terhadap Kepuasan Kerja}

Berdasarkan tabel uji t diperoleh nilai sig $0.000<0.05$, sehingga Ho ditolak dan H1 diterima. Tetapi mempunyai pengaruh yang positif dengan nilai koefisien B sebesar 0.494. Dengan demikian dapat dikatakan bahwa terdapat pengaruh positif secara signifikan kompensasi terhadap kepuasan kerja.

\section{e. $\mathrm{H}_{5}$ Pengaruh antara Lingkungan Kerja terhadap Keinginan Berpindah}

Berdasarkan tabel uji t diperoleh nilai sig $0.018<0.05$, sehingga Ho ditolak dan $\mathrm{H} 1$ diterima dan mempunyai pengaruh yang negatif dengan nilai koefisien $\mathrm{B}$ sebesar 0.214. Dengan demikian dapat dikatakan bahwa terdapat pengaruh negatif secara signifikan lingkungan kerja terhadap keinginan berpindah.

\section{PENUTUP}

Simpulan

Berdasarkan hasil pengolahan dan analisis terhadap keseluruhan data yang diteliti, kesimpulan yang dapat diperoleh adalah kompensasi berpengaruh negatif terhadap keinginan berpindah karyawan PT Panin Bank Tbk. Artinya, bila kompensasi karyawan meningkat, maka akan menurunkan keinginan berpindah karyawan. Kemudian kompensasi berpengaruh positif terhadap kepuasan kerja karyawan PT Panin Bank Tbk. Artinya, bila kompensasi karyawan meningkat, maka akan meningkatkan kepuasan kerja karyawan. Kemudian lingkungan kerja berpengaruh negatif terhadap keinginan berpindah karyawan PT Panin Bank Tbk. Artinya, bila lingkungan kerjanya baik, maka akan menurunkan tingkat keinginan berpindah karyawan. Lingkungan kerja berpengaruh positif terhadap kepuasan kerja karyawan PT Panin Bank Tbk. Artinya, bila lingkungan kerja sesuai dan memadai, maka akan meningkatkan kepuasan kerja karyawan itu sendiri. Lalu kepuasan kerja berpengaruh negatif terhadap keinginan berpindah karyawan PT Panin Bank Tbk. Artinya, bila kepuasan kerja karyawan meningkat, maka akan menurunkan keinginan berpindah karyawan itu sendiri. 


\section{Saran}

Untuk penelitian selanjutnya disarankan menggunakan uji analisis yang berbeda dan menggunakan objek penelitian yang berbeda juga dikarenakan pada penelitian ini hanya memakai metode regresi berganda. Hasil penelitian ini disarankan dapat digunakan sebagai bahan introspeksi atau pembanding pada metode yang sudah diterapkan saat ini oleh PT Panin Bank Tbk Jakarta dalam rangka peningkatan kuantitas pegawai.

\section{DAFTAR PUSTAKA}

Cox, S.J, and Cheyne, A.J.T. 2000. Assessing Safety Culture in Offshore Environments. UK: Safety Science 34.

Daft, Richard L. 2008. Management. USA: Thomson Higher Education.

George, Jennifer M. Georges. Jones, Gareth R. 2012. Understanding and Managing Organizational Behavior. New Jersey: Pearson Education Inc.

Gomes, Faustino Cardoso. 2003. Manajemen Sumber Daya Manusia. Yogyakarta: Andi.

Handoko, Hani. 2002. Manajemen Personalia Dan Sumber Daya Manusia. Yogyakarta: BPFE.

Locke, Edwin A. 2009. Handbook of Prinsicples of Organizational Behavior. UK: John Wiley \& Sons, Ltd.

Robbins, Stephen. Judge, Timothy. 2013. Organizational Behavior. USA: Pearson Education.

Robbins, Stephen P. Coulter, Mary. 2012. Management. New Jersey: Prentice Hall.

Schermerhorn, John R. 2010. Organizational Behavior. New Jersey: John Wiley \& Sons Inc.

Schneider, Benjamin. Smith, D. Brent. 2004. Personality and Organizations. London: Lawrence Erlbaum Associates, Inc.

Sugiyono. 2017. Metode Penelitian Kuantitatif, Kualitatif, Dan R\&D. Bandung: Alfabeta, CV.

Supriyadi, Edy. 2014. SPSS+AMOS. Jakarta: In Media.

Umar, Husein. 2010. Desain Penelitian MSDM Dan Perilaku Karyawan. Jakarta: Rajawali Pers.

Widodo, Rohadi. 2010. "Analisis Pengaruh Keamanan Kerja Dan Komitmen Organisasional Terhadap Turnover Intention Serta Dampaknya Pada Karyawan Outsourcing." Universitas Diponegoro. 